\title{
Inhibition of KSHV-associated lymphoma engraftment in SCID mouse by morpholino oligomers
}

\author{
Yuchen Nan*, Deendayal Patel, Yanjin Zhang \\ From $12^{\text {th }}$ International Conference on Malignancies in AIDS and Other Acquired Immunodeficiencies \\ (ICMAOI) \\ Bethesda, MD, USA. 26-27 April, 2010
}

Kaposi's sarcoma-associated herpesvirus (KSHV), also known as human herpesvirus 8 , is associated with several malignant disorders, including Kaposi's sarcoma, primary effusion lymphoma (PEL), and multicentric Castleman's disease. We have explored peptide-conjugated antisense phosphorodiamidate morpholino oligonucleotides (PPMOs) against KSHV and found effective PPMOs in inhibition of KSHV gene expression in cell culture. PPMOs are single-stranded DNA analogues that have a modified backbone and penetrate cells readily. In this study, we further tested the PPMOs in a SCID mouse model to assess their effect on engraftment and growth of PEL cells. PEL cells were engrafted into SCID mice via intraperitoneal route. PPMO was administered at the same time and repeated every other day for 10 doses. The mice were observed and scored for ascites development. The tumor cell burden was assessed by flow cytometry. Administration of anti-vIL-6 PPMO protected the mice from lymphoma development, while those mice receiving a control PPMO developed ascites and had high ratio of PEL cells in peritoneal lavage. The results demonstrate that PPMO against key KSHV genes can potently reduce KSHV replication and growth of PEL cells in SCID mice. Further exploration of PPMOs in the animal model is warranted.

\section{Acknowledgements}

This article has been published as part of Infectious Agents and Cancer Volume 5 Supplement 1, 2010: Proceedings of the $12^{\text {th }}$ International Conference on Malignancies in AIDS and Other Acquired

\footnotetext{
* Correspondence: zhangyj@umd.edu

Department of Veterinary Medicine and Maryland Pathogen Research Institute, University of Maryland, College Park, MD, USA
}

Immunodeficiencies (ICMAOI). The full contents of the supplement are available online at http://www.biomedcentral.com/1750-9378/5?issue=S1.

Published: 11 October 2010

doi:10.1186/1750-9378-5-S1-A40

Cite this article as: Nan et al:: Inhibition of KSHV-associated lymphoma engraftment in SCID mouse by morpholino oligomers. Infectious Agents and Cancer 2010 5(Suppl 1):A40.
Submit your next manuscript to BioMed Central and take full advantage of:

- Convenient online submission

- Thorough peer review

- No space constraints or color figure charges

- Immediate publication on acceptance

- Inclusion in PubMed, CAS, Scopus and Google Scholar

- Research which is freely available for redistribution

Submit your manuscript at www.biomedcentral.com/submit
C Biomed Central 